\section{German Institute for International and Security Affairs (Stiftung Wissenschaft und Politik; SWP)}

Founded 1962. Independent scientific establishment that conducts practically oriented research on the basis of which it then advises the Bundestag and the German federal government on foreign and security policy issues. Research divisions: EU integration; EU external relations; international security; the Americas; Russian Federation/CIS; Middle East and Africa; Asia; global issues.

Address: Ludwigkirchplatz 3-4, 10719 Berlin, Germany.

Website: http://www.swp-berlin.org

Director: Prof. Dr Volker Perthes.

\section{Heritage Foundation}

Founded 1973. Conservative think tank aiming to formulate and promote public policies based on the principles of free enterprise, limited government, individual freedom, traditional American values and a strong national defence. Target audience includes members of Congress, key congressional staff members, policymakers in the executive branch, the news media, and the academic and public policy communities.

Address: 214 Massachusetts Ave., NE, Washington, D.C., 20002-4999, USA.

Website: http://www.heritage.org

President: Edwin J. Feulner.

\section{Hoover Institution (on War, Revolution and Peace)}

Founded in 1959 at Stanford University. Originated from research network built up by the Hoover War Library. Aims to secure and safeguard peace, improve the human condition and limit government intrusion into the lives of individuals. Three overarching research programmes focus on American institutions and economic performance, democracy and free markets, and international rivalries and global co-operation.

Address: 434 Galvez Mall, Stanford University, Stanford, CA 94305-6010, USA.

Website: http://www.hoover.org

Director: John Raisian.

\section{Human Rights Watch}

Founded 1978. Non-profit, non-governmental organization dedicated to protecting the human rights of people around the world. Research topics include: arms; children's rights; counterterrorism; disability rights; health; international justice; migrants; press freedom; refugees; terrorism; torture; women's rights.

Address: 2nd Floor, 2-12 Pentonville Road, London N1 9HF, UK.

Website: http://www.hrw.org

Executive Director: Kenneth Roth

\section{Institute for Government}

Founded 2008. Independent charity that works with all the main political parties at Westminster and with senior civil servants in Whitehall to increase government effectiveness. Undertakes research, provides development opportunities for senior decision makers and organizes events for leading international experts to share new thinking on best government. Areas of work: a more effective Whitehall; better policy making; new models of governance and public services; parliament and the political process; leadership for government.
Address: 2 Carlton Gdns, London SW1Y 5AA, UK. Website: http://www.instituteforgovernment.org.uk Director: Rt Hon Peter Riddell CBE.

\section{Institute of World Economy and International Relations}

Founded 1956. Non-profit organization that carries out applied socio-economic, political and strategic research. Research areas include: current global problems; economic theory; economic, social and political problems of the transition period in Russia; forecasting and analysis of world economy dynamics and sociopolitical developments; international politics; military and strategic problems; theory of international relations; theory of social and political processes.

Address: 23 Profsoyuznaya St., Moscow 117997, Russia.

Website: http://www.imemo.ru

Director: Alexander A. Dynkin.

\section{International Crisis Group}

Founded 1995. Independent, non-profit organization committed to preventing and resolving deadly conflict. Combines field-based analysis, policy advice and high-level advocacy to highlight potential future conflicts, resolve peace negotiations and advise governments and intergovernmental bodies.

Address: 149 avenue Louise, Level 24, B-1050 Brussels, Belgium. Website: http://www.crisisgroup.org

President: Louise Arbour.

\section{International Institute for Strategic Studies (IISS)}

Founded 1958. Independent organization, considered the world's leading authority on political-military conflict. Research programme themes: conflict; defence and military analysis; economics and conflict resolution; non-proliferation and disarmament; transnational threats and international political risk; transatlantic dialogue on climate change and security.

Address: Arundel House, 13-15 Arundel St., Temple Place,

London WC2R 3DX, UK.

Website: http://www.iiss.org

Director-General: Dr John Chipman.

\section{Kiel Institute for the World Economy (Institut für Weltwirtschaft an der Universität Kiel; IfW)}

Founded 1914. Independent, international centre for research in global economic affairs, economic policy consulting, economic education and documentation. Research areas: the global division of labour; knowledge creation and growth; the environment and natural resources; poverty reduction, equity and development; monetary policy under market imperfections; financial markets and macroeconomic activity; reforming the welfare society.

Address: Hindenburgufer 66, 24105 Kiel, Germany.

Website: http://www.ifw-kiel.de

President: Prof. Dennis Snower.

\section{Konrad Adenauer Foundation (Konrad-Adenauer-Stiftung)}

Founded in 1955 as the Society for Christian Democratic Civic Education and renamed in 1964. Political foundation that focuses on consolidating democracy, the unification of Europe and the 